\title{
Bilingualism and Language Education in French Primary Schools: Why and How Should Migrant Languages be Valued?
}

\author{
Christine Helot and Andrea Young \\ G.E.P.E., (Groupe d'Etude sur le Plurilinguisme Européen), EA3405, Université \\ Marc Bloch, 22 rue Descartes, 67084 Strasbourg, Cedex, France
}

While bilingual education programmes in European mainstream languages are becoming increasingly popular in France, the bilingualism of migrant children remains overlooked and is believed by many to delay the acquisition of French. An institutionalised language hierarchy lies all too often unchallenged within the French education system and linguistic policies for primary schools, while trying to develop foreign language learning from the earliest age, fail to deal with the question of minority languages. This study presents a language awareness project in a small primary school in the Mulhouse area of Alsace as an example of how languages of unequal status can be placed on an equal footing in a school context, how children can be educated to linguistic and cultural variety and teachers made aware of the linguistic and cultural wealth present in their classes and their community. Finally, we shall argue that language awareness programmes do not have to compete with early foreign language teaching, but can be implemented in a complementary way, to educate children about language, languages and cultures, thus valuing differences as a source of learning, helping to foster tolerance and fight racism and extending teachers' knowledge and understanding of multilingual and multicultural issues.

\section{Introduction}

There is a sharp contrast in France between the very strong priority given to foreign language teaching (FLT) at primary level and the reluctance to acknowledge the many 'migrant' cultures and languages spoken by a growing number of children in French classrooms. As in other European countries, the status of the languages concerned is a major factor; while European languages are highly valued socially and economically, the languages of immigrant populations are associated with poverty and former domination. The failure to support the bilingualism of children from migrant backgrounds is all the more glaring in the face of the considerable efforts and finance invested in the teaching of European languages and early bilingual education programmes in prestigious languages.

This article proposes to explore the factors which have led to the implementation of such educational policies and argues for the acknowledgement and valuing of the bilingualism of migrant children for society as a whole. The presentation of a language awareness project in a school in Alsace illustrates how teachers and children can be educated to understand linguistic and cultural diversity, and how migrant languages and cultures can be legitimised alongside regional or mainstream European languages. 


\section{Multilingualism and Multiculturalism in French Schools}

\section{Political background}

France, because of its constitution, has developed an assimilationist model of integration with ideals of equality for all its citizens sharing the same language and the same culture. The mainstay of its education system is that all children should be treated equally and that therefore no differentiation should be made according to social, religious, ethnic or political background. The use of a single standard language symbolises the unity of the country and ensures that the nation is indivisible. This is one of the reasons behind the reluctance to refer to 'minorities' and 'minority languages' in France.

The term used to refer to the languages spoken by immigrant populations is 'languages of origin' (langues d'origine) suggesting that everyone should speak French even if 'originally' another language was part of the person's life. Such terminology (as opposed to 'heritage', 'community', or 'patrimonial' used in other countries) reinforces negative representations of migrant languages (ML) and their speakers, separation from other non-indigenous languages in France, and is one of the reasons why the bilingualism of migrant children is largely ignored in schools (Helot, 1997). Other researchers have described this type of bilingualism as 'invisible' (Martin-Jones and Romaine, 1986) or 'forced' (Vermes $\&$ Boutet, 1987), meaning the children have no choice but to be schooled through French. In general, children in France are schooled from a very early age (usually three, but sometimes as young as two) with the belief that, for children from migrant backgrounds, very early schooling will help them to acquire the necessary linguistic competence in French to cope in primary school (age six). For 'languages of origin' are still perceived in French schools as the main obstacle to the acquisition of the French language and as a source of learning difficulties. This explains why the term bilingual, which has many positive connotations in French society today, is never used in official texts to refer to children from migrant backgrounds. It is reserved for the acquisition of mainstream European languages and for immersion programmes in Brittany, Alsace, the Basque country, etc.

However, the issue of multilingualism and multiculturalism in the French educational context has been addressed very recently by the Minister for Education: 'France is not a monolingual country, contrary to widespread opinion. Its future lies in the respect of cultural and linguistic diversity and the development of multilingualism' (Lang, 2001, our translation), probably under the growing pressure from European institutions to acknowledge regional, minority and immigrant languages within the context of a multicultural Europe (Charter on Regional and Minority Languages of the Council of Europe, 1992; the Framework Convention on National Minorities of the Council of Europe, 1995; The Universal Declaration of Linguistic Rights, 1996; the Declaration of OEGSTGEEST by the European Cultural Foundation, 2000; The European Year of Languages, 2001 etc.). Nevertheless, it should be noted that the speech was delivered within the context of a reform in the teaching of mainstream European languages and that while some measures have been taken regarding regional languages (giving rise to strong protests from teachers' unions), the declarations concerning MLs remain on the level of good intentions, and leave teachers and 
teacher trainers with no concrete directives. When one reads in a teachers' magazine (Echos-PI, 2001) for example that a child of migrant background cannot speak, when if fact what is meant is that the child cannot speak French, it is most important to ask why some children are silenced in school, why their home languages are ignored and what kind of tools teachers can be given (Dabène, 1994) to have a better understanding of linguistic and cultural diversity.

\section{Language Policies in Education}

\section{The French language as 'the priorities of priorities'}

At present, the French National Curriculum is based on language policies which reaffirm the 'absolute priority' (Lang, 2001) of the French language for all pupils. Furthermore, in the face of what are felt to be 'threats' (the English language, regional and migrant languages, non-standard varieties of French: Ager, 1999) to the language of the state, teachers tend to give priority to the teaching of written French and to prefer a rather normative approach. In this context, children from migrant backgrounds are expected to have or to acquire native speaker competence as quickly as possible and are not supposed to use their home language in school. A different case is made for foreign children who have just arrived in France. They are enrolled in special classes where they are taught minimum skills in French and encouraged to join the mainstream programme as soon as possible. In the regular classes, teachers are not trained to deal with the problems of second language acquisition (which is often confused with foreign language acquisition); most of them are white, middle-class, from monolingual backgrounds and therefore have little sensitivity to what it means 'to leave your language at the door' when you enter school. As Moore (1996: 1) writes: 'One should not forget either that for many, the language of origin remains the only wealth, the sole hidden treasure in an environment which is not always as welcoming as one would expect'.

After the teaching of French, the next priority of the French education system is to develop the teaching of foreign languages (FLT) from the earliest age. The Minister for Education's latest declaration (Lang, 2001) aims at starting FLT at kindergarten level (age three) by 2005 (FLT currently starts at age nine), while the teaching of migrant languages (ML) has not been addressed.

\section{The provision for languages other than French in primary schools}

Languages other than French present in primary schools are labelled as either 'modern foreign languages' (for example English, German, Spanish, Italian, etc.), 'regional languages' (Alsatian, Corsican, Provençal, Basque, Breton, etc.) or 'languages of origin' (Arabic, Turkish, Spanish, Portuguese, Italian, etc.). Table 1 compares the current organisation of FLT and migrant language teaching (MLT) in primary schools and shows that some languages are present in both columns. Indeed, 'languages of origin' reflect the migration patterns into France; Spanish and Italian people are now considered as completely assimilated into mainstream French society and the construction of Europe has enabled these languages to move into a better status category. Education legislation though has not followed through in the sense that some languages still belong to the category 
Table 1 Comparative table showing the provision for FLT and MLT in the primary sector in France

\begin{tabular}{||l|l||}
\hline \hline $\begin{array}{l}\text { Foreign Language Teaching } \\
\text { English German Italian Spanish (Arabic } \\
\text { since 1995 in theory only) }\end{array}$ & $\begin{array}{l}\text { Italian Spanish Portuguese Arabic Turkish } \\
\text { (Serbo-Croat) Polish }\end{array}$ \\
\hline 1.5 hours/week & 3 hours/week \\
\hline Compulsory & Optional \\
\hline $\begin{array}{l}\text { Final two years of primary education } \\
\text { (aged 9-11) Instructions officielles 1998 }\end{array}$ & $\begin{array}{l}\text { Possible from first year of compulsory } \\
\text { education (aged 6) onwards }\end{array}$ \\
\hline $\begin{array}{l}\text { Language chosen by the parents (in } \\
\text { theory) - English 90\% }\end{array}$ & Language chosen by the parents \\
\hline $\begin{array}{l}\text { Willing class teacher or other school } \\
\text { teacher }\end{array}$ & Foreign teacher from outside school \\
\hline Always during class time & $\begin{array}{l}\text { During class time (replaces other } \\
\text { activities) or outside class time }\end{array}$ \\
\hline Funding: local council 15FF/child & Funding: foreign government \\
\hline Continued in secondary school & Not usually continued \\
\hline
\end{tabular}

of migrant languages when there are no longer migrant workers coming from these countries.

This classification not only reflects the different status of the languages concerned, it creates an inbuilt hierarchy (as well as rivalry) and in reality a great lack of choice for children at primary level. English is taught to over $90 \%$ of children in their last year of primary school. German is taught almost exclusively in most classes in Alsace but very little in the rest of France, and Spanish is even rarer. Arabic, which was included in the official texts of 1995 as a foreign language, is never taught within that provision.

The place allotted to languages in the curriculum does not give the same value or legitimacy to ML as to FL, thus creating an inequality which young children must perceive, and which also influences teachers' attitudes towards different languages and their speakers. While FLT is an integral part of the primary curriculum, MLT remains optional, and takes place mostly outside school hours. When it is included in the regular timetable, it has the effect of placing languages in competition or of singling out children (they are taken out of the regular class). When it takes place outside school hours it reduces the child's free time and also segregates children. The ML teacher is not the regular class teacher (as in most cases for the FL), but a peripatetic teacher of foreign nationality. Therefore, it is difficult for him/her to make links with other subjects and sometimes even to communicate with permanent school staff.

The teaching aims of ML and FL are also different. FLT is seen as essential not only in economic, social and cultural terms but also as having cognitive benefits for the child while MLT was originally intended in view of a possible return to the country of origin and is now a way of preventing such courses from taking place outside schools, in a bid to ensure secular lesson content, especially in the cases of Islamic countries of origin (NB the mainstream French state education system is strictly secular). 


\section{Minority Children in France and Bilingualism: Pedagogical Consequences}

The widespread negative perceptions of bilingualism with reference to children from migrant backgrounds have pedagogical consequences which urgently need to be addressed in the French educational context.

\section{Negative perceptions of bilingualism}

Cummins $(1980,1981)$ and Grosjean (1985) have shown that negative perceptions of bilingualism come from having a monolingual view of what it is to function in two or more languages. For example, most teachers still believe that speaking a ML at home delays the acquisition of French (and consequently integration into French society). They are not aware of the research on cognitive theories of bilingualism and the curriculum which has demonstrated the importance of maintaining the home language for the development of the school language (Cummins, 1976, 1978; Toukomaa \& Skutnabb-Kangas, 1977). They do not know either the work of different researchers in Europe on the education of minorities: Baetens-Beardsmore (1993), and Sierra and Olazigeri (1991) in the Basque country, Byram and Leman (1990) in Brussels, Dabène and Billiez (1992) in France, Hsia (1982) in London, Extra and Gorter (2000), etc.

This is not the case in Belgium, to take an example close to France, where the 'Foyer Project' in particular is well known. Set up in Brussels in 1981 as an experiment in mother tongue education for minority children, it has shown convincingly (Danesi, 1990) that proficiency in both the mother tongue and the school language are interdependent and that

literacy development in the mother tongue contributes the primary condition for the development of global language proficiency and the formation of the appropriate cognitive schemas needed to classify and organise experience. (Danesi, 1990: 65)

French teachers need to understand that the source of these children's learning difficulties is not rooted in the use of the home language by immigrant parents, but rather in the lack of support and recognition for their languages, and the reluctance to admit that these children are bilinguals since they 'function' (Fishman, 1965) in two languages. As Baker (1996: 148) writes:

If children are made to operate in an insufficiently developed second language the system will not function at its best ... and when one or both languages are not functioning fully (because of pressure to replace the home language with the majority language), cognitive functioning and academic performance may be negatively affected.

Unfortunately Baker's very useful publications for parents and teachers (1995) and for professionals (2000) are not translated into French. They could help teachers go beyond a rather xenophobic discourse (Clement \& Girardin, 1997) which holds the bilingualism of migrant children responsible for linguistic delay, underachievement, identity problems and placing an extra burden on the teaching profession.

Another commonly held belief is that the language used at home by migrant 
parents is not a legitimate linguistic model. Because these parents' knowledge of French is not seen as fluent, it is also often mistakenly assumed that they have poor linguistic abilities in their first language, when indeed research has shown high levels of literacy in home languages in families of migrant background (Deprez, 1994; Leconte, 1997; Martin-Jones \& Jones, 2000).

The phenomenon of code-switching and code-mixing in bilingual speech is not familiar either to most teachers whose training does not yet include any sociolinguistic study. It is often interpreted as confusion in the child's mind and assessed as delay in the acquisition of French because teachers are not aware of the extensive research on the matter which has shown that code-switching and code-mixing is a natural and usual feature of bilingual speech (Clyne, 1967; Harding \& Riley, 1986; Hoffmann, 1991; Romaine 1989). As Saunders (1988: 56) writes: 'It is very rare to find a bilingual person, child or adult, who can completely avoid one of his or her languages influencing the other in some way or other'.

If policy makers in France want to tackle the education of minorities seriously, they need to acknowledge the importance of mother tongue education for bilingual children. To quote Baker (1996: 226) again:

For bilingual children the school is usually an essential agent in developing the home, native, heritage language. When a child enters kindergarten or elementary school, first language development needs to be formally addressed, irrespective of whether that child has age appropriate competency or not in the home language. While first language development throughout schooling is important for majority and minority language children, the minority context places extra reasons for careful nurturance of a minority language.

\section{Restrictive perception of bilingualism}

The literature published in France, because its principle aim is to support early FLT, promotes the view that FL learning is easy and provides not only negative but restrictive definitions of bilingualism. A recent book on bilingualism written by a renowned French linguist (Hagège, 1996) reinforces a narrow perception of bilingualism, maintaining that to be bilingual means to speak two languages perfectly.

French people think they are not very good at languages, whereas I hope to show in this book, that any French person can become a perfect bilingual, given that favourable conditions are in place'. (Hagège, 1996: 14, our translation, our emphasis).

Such a statement equates bilingualism with perfect competence in two languages and ignores the work of most authors in the field (Baetens-Beardsmore, 1982; Baker, 1996; Bloomfield, 1933; Grosjean, 1985; Haugen, 1953;Mackey, 1962; Romaine, 1989; Saunders, 1988; Van Overbecke, 1972, etc.) who have insisted on the importance of the relative nature of bilingualism. Indeed, perfect bilingualism is an ideal of the same type as perfect monolingualism. As Baker (1995: 41) writes:

This idea of balanced bilinguals, perfectly balanced in both their languages, 
is one muddled myth that surrounds bilingualism. This myth is part of a monolingual view of the world ... The reality that surrounds most bilinguals is very different. Languages have purposes. For a bilingual each language tends to have different purposes, different functions and different uses.

Restrictive definitions of bilingualism, such as Hagège's quoted above, reflect a monolingual view of language functioning; they also confuse a supposed perfect competence with native like competence and do not take into account the fact that language competence, whether in one or several languages, varies according to many factors. In view of such misconceptions and attitudes, the French education system should start to challenge representations which contribute to the perpetration of inequalities in French classrooms.

\section{Bilingual issues and teacher education}

Understanding all the issues that surround linguistic and cultural plurilingualism in our society is not easy for primary teachers who are under pressure to implement a fairly heavy curriculum to which FLs have been recently added. While their initial teacher education now includes a European language, the content of courses deals primarily with linguistic proficiency and the didactics of one specific language; no cross-curricular links are made with other languages and too few with the didactics of French or other subjects (e.g. citizenship education could easily incorporate some reflection on multilingualism and multiculturalism or intercultural education).

Hence teachers are not aware that languages are in contact not only in society at large, but in the classroom, as well as within individual bilingual or trilingual children, and that as stated by Cummins (2000: 34):

Students' identities are affirmed and academic achievement promoted when teachers express respect for the language and cultural knowledge that the children bring to the classroom and when the instruction is focused on helping students generate new knowledge, create literature and art and act on social realities that affect their lives.

They do not realise either that ignoring the home language and culture of a child at school also has consequences on her affective development and consequently on her ability to learn. If learning is interpreting and understanding the world around us, including clues from cultural input (Donaldson, 1978), home experiences cannot be cut off from school experiences because children build on the knowledge acquired in their home environment and bring a range of knowledge, skills and experience to the classroom which cannot be ignored. As Vygotsky wrote: 'Children's learning begins long before they attend school so any learning encountered in school by a child has a previous history' (1978: 84).

We believe that within the French context, it is up to teacher educators dealing with majority languages to include issues concerning all languages (minority, immigrant, regional and others, as well as the majority language) in a non-exclusive way, to propose ways of valuing the linguistic competencies of all children (Lang, 2001) and consequently to value the bilingualism of children from migrant backgrounds. In short, a more global perspective as well as a 
cross-curricular approach should be adopted in order to help teachers move away from a monolingual habitus.

Indeed, some school based projects have started to tackle the issue of multilingualism and multiculturalism and even if they are isolated initiatives such as the one run by the small rural school of Didenheim (on the outskirts of Mulhouse in Alsace), they can serve to illustrate how diverse languages and cultures can be supported and valued in the primary school.

\section{Linguistic and Cultural Diversity Education: The Didenheim Language Awareness Project}

\section{History and context of the project}

The impetus for the Didenheim project originated from primary teachers who were keen to take a pro-active stance towards linguistic and cultural parochialism within the school and the community at large.

Although Didenheim is a small rural school (84 children in total), $37 \%$ of the children are recorded as other than of French origin (Arabic: 10.7\%, Turkish: 9.5\%, Polish: $4.7 \%$, Portuguese: $2.4 \%$, Italian: $2.4 \%$, other: $4.7 \%$, plus another $4.7 \%$ who come from Alsatian-speaking homes). Only eight children are recorded as non-French nationality (one Moroccan and seven Turkish). Some of the children are in contact with more than one language as in the case of one pupil whose mother is Malaysian and speaks Malay to her child, but English to her Alsatian husband.

Prior to the project, during their final two years of primary schooling, the children of Didenheim, aged 9 to 11, were taught German (the children or parents had no other choice of FL) which constituted their first formal FLL experience. The school was confronted with a twofold problem: a lack of motivation on the part of the children to learn German and an increase in the number of racist incidents within the community. It was decided to tackle these problems by raising the profile of all languages within the school, and centring the next three year long school project on the theme of language and cultural diversity.

The project (started in September 2000) involves children from the first three classes of compulsory primary schooling, aged from six to nine, 12 parents and four teachers. The languages concerned are (in order of presentation): Alsatian (local dialect), Japanese, Vietnamese, Malay, Mandarin, Spanish, Finnish, Brazilian Portuguese, Serbo-Croat, Polish, Italian, Turkish, Arabic, Berber, German and English. They represent the languages which are spoken by the parents (some speak two or three) who have agreed to participate (all parents were sent a circular explaining the project and inviting them to take part).

The children are asked to participate in activities during which they are presented with a wide range of linguistic and cultural materials associated with a particular language by one or two parents working with the teacher. Project and topic work is encouraged and the linguistic environment of the class/school/local community is used wherever possible, all within a pedagogical framework of discovery. 


\section{Objectives of the project}

The objectives outlined by school staff in conjunction with the parents and a member of the local education authority are:

To bring the children into contact with other languages and to sensitise them to the use of languages, to familiarise the children with other cultures through the presentation of festivals, traditions, costumes, geography ..., and last but not least to promote the acceptance of differences, to learn about others and to attempt to break down stereotypical misconceptions. (Minutes from school project meeting, 7 October 2000, our translation)

The teachers thought the children should be presented with a larger pallet of languages before beginning formal FLL, that they should be introduced to the sounds of languages with which they do not normally come into contact within the school context and confronted with different writing systems and cultural habits. They hoped such activities would make the children aware of the richness of languages and cultures in the world, awaken their natural curiosity and develop a spirit of tolerance.

\section{Implementation of the project}

The decision to begin the project with the study of the local dialect of Alsatian and local customs was both of a logical and a politically strategic nature. Apart from the fact that the project began in the month of November and that Christmas time is particularly rich in Alsatian customs and traditions, starting with a language variety which was present within the local community, and therefore familiar to the children to a certain extent, allowed the project to take root in the surrounding environment. The children were thus invited to examine the language phenomenon closer to home before transposing it to more exotic locations of the globe. In addition, inaugurating the project with the study of a ML and culture would, it was thought, jeopardise wider parental and community support and might then serve as a vector for division rather than for the drawing of parallels and the broadening of visions. Furthermore, in an area such as Alsace, where linguistic identity has historically often been dictated and imposed upon the population by the authorities and where any form of education involving languages is often regarded with suspicion, it was considered prudent to acknowledge local variation before venturing into the global arena.

On the pedagogical level, the project is based on parent-teacher collaboration and a cross-curricular approach. Parents with a knowledge of any language other than French run Saturday morning sessions (in France regular school classes also take place on Saturday mornings) with the class teacher who participates in the activities along with the children, so that she may reactivate what has been learned during the sessions and make links with other subjects and activities throughout the school week. Each language may be allotted one or a series of Saturday morning sessions. Regular preparation and feedback meetings are organised for participating parents and class teachers as the project progresses.

The activities proposed by the parents have included: telling stories with cultural and personal content (e.g. growing up in Vietnam before the war), reading traditional tales from bilingual books, tasting specialities from different culi- 
nary traditions (cooking and learning to eat Vietnamese food with chopsticks, sitting on mats with feet pointing properly), learning to sing short songs with actions (Happy Birthday was learned in most languages taught in the first year), learning about the geography and history of the countries concerned (each language was presented within its geographical context and children made poster presentations for each country which are kept in the school library), talking about lifestyles and living conditions in different countries (the Malay parent decorated the school for Chinese New Year with bamboo and red garlands, the children were asked to come to class wearing bright red, green or yellow and they were given Chinese coins in small red envelopes as good luck tokens to be kept unopened the whole year), learning how to introduce oneself (after having chosen a Vietnamese first name and learned its meaning), greet and say please and thank you in context (for example when the sushi were offered during the Japanese session) as well as basic vocabulary such as colours or fruits, listening to different sounds and learning to differentiate (e.g. hearing and repeating words containing the four tones of Mandarin), looking at the different scripts used for writing the languages (Mandarin, Malay, Japanese for example) as well as diacritic signs (Vietnamese, Finnish), highlighting linguistic borrowings and guessing meaning from transparent words (e.g. Vietnamese from French, Finnish from English), drawing parallels between languages (Alsatian and German, Portuguese and French, etc.) and negotiating meaning from context or pictures (e.g. the Finnish video tape where the children comment on a football game taking place in their school or show their school canteen).

The parents' presentations varied enormously in content as well as format, and showed the influence of their respective culture: the Finn showed a video presentation Finnish children had made for the Didenheim children about their school in the forest and talked about animals in the Great North, the Brazilian gave a power point presentation of Brazil centred on football, the Japanese speaking parent came dressed in traditional costume and taught rules of politeness and some kanji. All of them based their sessions on both linguistic and cultural aspects as outlined in the project objectives.

\section{Methodology}

Observations and video recordings of all sessions focus in general on the children's learning attitudes, whether they are keen to participate in the activities proposed, how they react to differences and in particular on their questions and comments which have been noted when they concern cultural aspects, linguistic features of the language (oral and written), metalinguistic remarks (whether spontaneous or prompted by teachers or parents) and general comments revealing attitudes towards the languages and their speakers. Semi-directed interviews with teachers were also carried out regularly.

The research objective is ultimately to identify what the children are learning. By 2003, some children will have taken part in the project for three years and we plan to look into the effects of their experience with language diversity on their formal FLL.

Regarding the teachers, we are interested in the way they are 'learning by doing' about a wide variety of languages and cultures, whether we can draw 
some principles for the training of future primary teachers and what kind of teaching materials need to be developed.

\section{Evaluation after one year (2000/2001)}

Observation of the children shows a high level of participation in the activities proposed, great curiosity and willingness to learn more about unfamiliar languages and cultures without making negative judgements (apart from comments on some of the food they tasted such as horse-radish biscuits from Vietnam!). Most children appear to have no difficulties in repeating sounds never heard before, distinguishing tones in Mandarin, noticing phonetic features. For example, during the Finnish session: a child noticed the phoneme /j/ was frequent in Finnish, another asked did the language also have /g/, another that there were a lot of rolled $/ \mathrm{r} /$ and the children started repeating words containing this phoneme. They noticed the morpheme 'balo' in the words used for football and basketball, another noticed that all written letters are pronounced in Finnish and concluded it would be easy to learn to read, and all children asked numerous questions about schools in Finland, forests and animals, Lapland, etc. At the end of the session one child said: 'I'm going to ask my Dad to take me to Finland on holiday'.

Older children tended to ask more questions about cultural content, while younger ones enjoyed repeating new sounds, listening to recordings of songs (in Mandarin, Malay, Japanese) on cassettes. The pertinence of the children's questions is worth quoting. For example, 'Why is Alsatian a dialect and not a language?', 'Why do Vietnamese people not have the same skin colour?', 'It's funny how Vietnamese has so many different accents, why is there a dot below and an accent on top?', 'What accent do Japanese people have?', 'Do all family names in Alsatian have meanings?', 'Is it hard to learn French when you are Chinese?', 'Are there pupil reps in Finnish schools?' etc. and by the end of the year observers were greeted with 'Which language are we learning today?'.

As far as the parents are concerned, using them as a classroom resource has proved positive. It has given them an opportunity to talk about themselves, to participate in the learning of their children and to share their languages and cultures with teachers and pupils thus providing them with a legitimate place at school.

While the involvement of parents in school life is a regular feature of other education systems, in France, parents are active in parent-teacher associations but are rarely invited inside the classroom. Immigrant parents are even more inhibited. Regarding this aspect, the Didenheim project is rather innovative and could be described in Cummins' (2000) terms as an 'educational partnership'. On the affective level, personal contact with unknown cultures through the parents could be more effective to combat stereotypes. As Komorowska (2000: 46): writes 'It is extremely difficult to generalise and give rise to stereotypes when personal contacts are established and friendships are born between individuals'.

Another positive consequence of the parents' involvement was that the project could start without the teachers having any special training. Indeed, the teachers are discovering linguistic and cultural variety along with the children. For example, they listen and repeat short sentences in languages they have never heard before (Finnish, Malay, Japanese), they learn about tones in languages like 
Mandarin, realise that Vietnamese uses the Roman alphabet and that Portuguese is spoken differently in Brazil and in Portugal, etc.

Their enthusiasm and curiosity has grown markedly throughout the year as they have discovered the extent of what they are learning. The language activities have also had an influence on their teaching as a whole as they have developed a more global perspective in other subjects through the links made with the various languages presented. In a sense what the school is doing is broadening its linguistic and cultural horizon and going beyond the limits set by the education system which are giving children one national language, imposing German as a FL and setting children of Arabic origin apart by offering them some classes in Moroccan.

The findings of our final evaluation will be reported in a subsequent paper. At this stage what the project shows is that any language and culture can be the support of language and cultural awareness activities. Thus the languages present in a school and its community whether migrant, regional, national or other, can all be placed on an equal footing, making children aware of the linguistic and cultural wealth of our world and demonstrating that difference is not deficiency, but a source of learning. By involving the parents, the school has started to forge closer links with the local community and between the children's home and school environments, and placed a special value on the bilingualism and in some cases multilingualism of parents and children. It should also be said that the mother who ran the Japanese session was French but has always had a keen interest in the Japanese culture and language (which she has been learning as an adult) and has visited the country once. This was explained to the children so as to give them an example of how it is possible to learn a language at any stage in one's life.

\section{Language awareness as an complementary model to language learning}

It should be pointed out that the teachers in Didenheim started the project very simply out of their desire for greater tolerance in their school and believing that they could tap into the linguistic and cultural diversity present in their community. They decided to design a cross-curricular project dealing with languages and cultures which revealed itself to be a very good, practical example of what specialists call 'language awareness'. They also made it clear that the project would not replace language teaching classes but would be offered to children prior to formal FLT.

The objectives of language awareness, as well as the pedagogical activities involved in this approach, are quite different from those of language learning. Language awareness activities imply coming into contact with a great variety of languages and cultures (including the language of schooling), reflecting upon differences and similarities and integrating these activities across the curriculum. It does not mean learning or acquiring a certain level of competence in these languages.

Language awareness projects started in the UK, in the wake of the Bullock Report (1975), where the work of Hawkins (1987) and Donmall (1985) is well known. 'Language awareness is a person's sensitivity to and conscious awareness of the nature of language and its role in human life.' (Donmall, 1985: 7). 
Other projects were developed as early as the 1970s in Australia (de Fazio, 1974) and since the 1980s, in France (Dabène, 1991; Dabène \& Billiez, 1992; Nagy, 1996), Germany (Haenisch \& Thürmann, 1995), Switzerland (De Pietro, 1995; Perregaux, 1998). In 1997, a Socrates Lingua funded project called 'Evlang' (Candelier, 1998) was started. It concerns children from eight to 11 years old, in La Réunion, Austria, France, Spain, Italy and Switzerland (the qualitative and quantitative evaluation of approximately 120 classes involved in 'Evlang' over three years is not yet available).

The concept of language awareness means developing a kind of language education which builds on two aspects: first a cognitive aspect (thinking about how language works and how different languages divide up reality) and second, an affective aspect with the aim of promoting tolerance, the understanding of differences and the respect of other languages and their speakers. Strong emphasis is also placed on the relationship between the mother tongue and other languages, be they foreign, regional or minority 'to challenge pupils to ask questions about language, which so many take for granted' (Hawkins, 1987: 4). In other words, insight into the functioning of one's own language can be gained through linguistic comparison with another language. In addition to the cognitive dimension, encouraging metalinguistic awareness, and the affective dimension, influencing and reshaping attitudes, there is a social/cultural dimension which recognises the inextricably intertwined relationship between language and culture, or language use within the context of a particular society.

As far as primary teacher education is concerned, it must be stressed here that to work within the objectives of language awareness does not involve the same investment in time as teaching a foreign language does. The competence needed is not the same, one is a matter of sensitivity and curiosity for languages, the other of having sufficient confidence in one's linguistic skills. As teacher educators and researchers, we know that primary teachers' lack of confidence in their FL competency is one of the major obstacles to tackle, and however attractive study periods abroad are, they are very costly.

This does not mean that language awareness should exclude early FLT, indeed they can be complementary approaches; but as Byram (2000: 57) writes: 'We have to admit that the fact of teaching FLs is not enough to guarantee either the development of a multilingual identity or other values such as tolerance, understanding of others and the desire for justice as is often proclaimed as a declaration of intent'.

In the same way, Brown and Brown in Britain report how initial teacher education for modern languages does not address the world context of language learning and that teachers 'need to be offered the chance to extend their knowledge and understanding of the world context of the language they are teaching' (1996: 100). In other words global perspectives should be explored in FL teacher education to make teachers aware of the potential offered for learning about other communities and cultures through studying a language. Language awareness activities could be a means of adopting a more global perspective in the classroom but we need to find out from present and further research whether such an approach fosters the development of positive attitudes and representations and can help teachers to begin to prepare pupils for their roles as future citizens. 


\section{Conclusion}

Language awareness is presented in this article as a possible model of language education which gives equal value and recognition to all languages irrespective of their status. While it does not answer the question of the education of minority children in the French educational context, it can be a first step towards giving some dignity to their home languages and some value to their bilingualism. Language awareness can also be of benefit to all children in fostering, from a very young age, a curiosity and motivation to learn about the wealth of languages and cultures present in the world. Furthermore, it may also provide a foundation in language education which helps to develop metalinguistic capabilities because links are made between the language of instruction and other languages. In teacher education, language awareness activities give teachers the chance to extend their knowledge of world issues and to address these in class across the curriculum.

Within the wider context of the work being done by various European institutions, the Didenheim project presented above, even if small scale, fulfils some of the objectives of the OEGSTGEEST declaration (European Cultural Foundation, 2000) 'Moving Away from a Monolingual Habitus' which states:

Affirmative conventions and action programmes on regional, minority and immigrant languages within the context of a multicultural Europe should be based on a non-exclusive acknowledgement of the existence of all these languages as sources of linguistic and cultural enrichment'. (Article 1)

Article 6 of the same declaration mentions that:

Education in regional, minority and immigrant languages should be offered, supervised and evaluated as part of the regular curriculum in preschool, primary and secondary education.

While this might take some time for the various education systems to implement and might also have the effect of restricting minority languages to minority pupils, language awareness, as a model which deals with different languages irrespective of their status, includes all children in its aims - the very aims of the European Year of Languages (Council of Europe/European Union, 2001), which are:

to increase awareness and appreciation among young people and adults ... of the richness of Europe's linguistic heritage, to celebrate linguistic diversity and promote it by motivating European citizens to develop plurilingualism'.

The conclusions of the Innsbruck conference in 1999 on 'Linguistic Diversity for Democratic Citizenship in Europe' go further than plurilingualism and suggest that a multiple linguistic sphere should be created in each European state and that 'linguistic policies should be put into place to help a person to develop a multilingual identity' (Cogolin, 2000: 49). Such a concept was felt to be central to the understanding that languages can be in contact and cooperate within the same linguistic sphere rather than compete.

In the same way, languages are in contact within bilingual individuals and 
should not have to compete on a scale of values determined by attitudes in society. Nor should they be silenced in school because of a perceived distance between the home language and culture and the language of instruction and the dominant culture. Rather it should be recognised that a child who speaks another language has an extra tool with which to interpret reality, to understand the world, and to learn.

Through language awareness activities, bilingual children can be given the opportunity to share with their peers and their teachers their personal experiences of speaking more than one language and of belonging to more than one culture. Teachers can thus begin to understand not only what it means to hold more than one identity but to realise that we all have composite identities which reflect the multiplicity and diversity of our belongings; as Maalouf (1998: 17) writes:

We should all be encouraged to assume our own diversity, to conceive of our identity as the sum of our multiplicity of belongings, instead of seeing our identity as singular and superior to others and raising it as an instrument of exclusion and sometimes an instrument of war. (Our translation).

More research on language awareness is needed to determine whether such an approach supports young children in building their linguistic and cultural identities, whether it has a positive effect on attitudes and representations and whether being in contact with a variety of languages encourages FLL motivation and helps pupils to learn other languages more efficiently.

What the Didenheim project shows at this stage is that language awareness activities can be a way of dealing with the growing variety of languages children from migrant backgrounds bring to school and with the consequent complex linguistic situations teachers have to face in their classrooms today (Kurdish children sit next to Turkish children in class, Kabyle children next to Algerians, African and Asian children do not all come from French-speaking countries, etc.) and that these factors rather than being obstacles to learning and teaching can be turned into an invaluable resource for educating children about tolerance, democratic citizenship and the global issues affecting our world today.

\section{Correspondence}

Any correspondence should be directed to Christine Helot and Andrea Young, I.U.F.M. d'Alsace, 200 Avenue de Colmar, 67100 Strasbourg, France (christine.helot@alsace.iufm.fr) (andrea.young@alsace.iufum.fr).

\section{References}

Ager, D. (1999) Identity, Insecurity and Image. France and Language. Clevedon: Multilingual Matters.

Baetens-Beardsmore, H. (1982) Bilingualism: Basic Principles. Clevedon: Tieto Ltd.

Baetens-Beardsmore, H. (ed.) (1993) European Models of Bilingual Education. Clevedon: Multilingual Matters.

Baker, C. (1995) A Parents' and Teachers' Guide to Bilingualism. Clevedon: Multilingual Matters.

Baker, C. (1996) Foundations of Bilingual Education and Bilingualism (2nd edn). Clevedon: Multilingual Matters. 
Baker, C. (2000) The Care and Education of Young Bilinguals: An Introduction for Professionals. Clevedon: Multilingual Matters.

Bloomfield, L. (1933) Language. New York: Holt, Rhinehart and Winston.

Brown, K. and Brown, M. (1996) A more rounded education: Global perspectives in modern languages and initial teacher education. In M. Steiner (ed.) Developing the Global Teacher, Theory and Practice in Initial Teacher Education (pp. 93-102). Stoke on Trent: Trentham Books.

Bullock, A. (1975) A Language for Life. Report of the committee of Inquiry appointed by the Secretary of State for Education and Science. London: H.M.S.O.

Byram, M. (2000) In La diversitélinguistiqueen faveur de la citoyennetédémocratiqueen Europe. Actes de Colloque. Strasbourg: Editions du Conseil de l'Europe.

Byram, M. and Leman, J. (1990) Bicultural and Trilingual Education. Clevedon: Multilingual Matters.

Candelier, M. (1998) L'éveil aux langues à l'école primaire, le programme européen 'Evlang'. In J. Billiez (ed.) De la didactique des langues à la didactique du plurilinguismeHommage à Louise Dabène (pp. 299-308). Grenoble: CDL - Lidilem.

Clement, F. and Girardin, A. (1997) Enseigner aux élèves issus de l'immigration. Paris: Nathan.

Clyne, M. (1967) Transference and Triggering. Observation on the Language Assimilation of Post-war German Speaking Migrants in Australia. The Hague: Niijoff.

Cogolin, I. (2000) In La diversitélinguistique en faveur de la citoyennetédémocratiqueen Europe. Actes de Colloque. Strasbourg: Editions du Conseil de l'Europe.

Cummins, J. (1976) The influence of bilingualism on cognitive growth. Working Papers on Bilingualism 9, 1-43.

Cummins, J. (1978) Metalinguistic development of children in bilingual education programs. In M. Paradis (ed.) Aspects of Bilingualism. Columbia: Hornbeam Press.

Cummins, J. (1980) The construct of language proficiency in bilingual education. In J.E. Alatis (ed.) Georgetown University Round Table on Languages and Linguistics, 1980. Washington DC: Georgetown University Press.

Cummins, J. (1981) The role of primary language development in promoting educational success for language minority students. In California State Department of Education (ed.) Schooling and Language Minority Students. A Theoretical Framework. Los Angeles: California State Department of Education.

Cummins, J. (2000) Language, Power and Pedagogy: Bilingual Children in the Crossfire. Clevedon: Multilingual Matters.

Dabène, L. (1991) L 'éveil au langage: Compte rendu d'une expérience en cours. In C. Luc (ed.) Les langues vivantes à l'école élémentaire. Paris: INRP.

Dabène, L. (1994) Repères sociolinguistiques pour l'enseignement des langues. Les situations plurilingues. Paris: Hachette.

Dabène, L. and Billiez, J. (1992) Autour du multilinguisme LIDIL (6). Presses Universitaires de Grenoble.

Danesi (1990) Mother tongue literacy and the 'shaping' of knowledge: The experience of the Italian children. In M. Byram and J. Leman Bilingual and Trilingual Education (pp. 64-76). Clevedon: Multilingual Matters.

De Fazio, A. (1974) Lingvo - Language Communication for Junior Secondary Students. Year One/Year Two. Drouin: Landmark Press.

De Pietro, J.F. (1995) Vivre et apprendre les langues autrement à l'école - une expérience d'éveil au langage à l'école primaire. Babylonia (2), 32-36.

Deprez, C. (1994) Les Enfants bilingues: Langues et familles. Paris: Didier CREDIF.

Donaldson, M. (1978) Children's Minds. Glasgow: Fontana/Collins.

Donmall, G. (ed.) (1985) Language awareness. N.C.L.E. Papers and Reports (6). London: C.I.L.T.

Echos-PI. (2001) Techniques Freinet pédagogie institutionnelle. Bulletin d'échanges 4. Aix en Provence: France.

Extra, G. and Gorter, D. (2000) The Other Languages of Europe. Demographic, Sociolinguistic and Educational Perspectives. Clevedon: Multilingual Matters.

Fishman, J. (1965) Who speaks what language to whom and when? La Linguistique 67-68. 
Grosjean, F. (1985) The bilingual as a competent but specific speaker-hearer. Journal of Multilingual and Multicultural Development 6 (6), 467-477.

Haenisch, H. and Thürmann, E. (1995) Begegnung mit Sprachen in der Grundschule. Eine empirische Untersuchung. Arbeitsberichte zur Curriculumentwicklung. Schule und Unterrichtsforschung, 30. Soest: Landinstitut für Schule und Weiterbildung.

Hagège, C. (1996) L'enfant aux deux langues. Paris: Odile Jacob.

Harding, E. and Riley, P. (1986) The Bilingual Family. A Handbook for Parents. Cambridge: Cambridge University Press.

Haugen, E. (1953) The Norwegian Language in America: A Study of Bilingual Behaviour. Bloomington: Indiana University Press.

Hawkins, E. (1987) Awareness of Language: An Introduction (Revised edn). Cambridge: Cambridge University Press.

Helot, C. (1997) Les dimensions sociales et affectives du bilinguisme précoce: Quelles incidences pour l'enseignement des langues à l'école? Université Marc Bloch, Strasbourg: Les Cahiers du CIRID (6).

Hsia (1982) Maintenance and recessiveness of home language among minority language Cantonese pupils in submersion programs. Bulletin de L'Institut de Phonétique. Bruxelles.

Hoffmann, C. (1991) An Introduction to Bilingualism. London: Longman.

Komorowska, A. (2000) In La diversitélinguistique en faveur de la citoyenneté démocratique en Europe. Actes de Colloque. Strasbourg: Editions du Conseil de l'Europe.

Lang, J. (2001) L'application du plan 'Langues vivantes à l'école primaire'. Discours de Jack Lang-29 Janvier 2001.(http:/ / www.education.gouv.fr/discours/2001/dlangviv.htm) Paris: Ministère de l'éducation nationale.

Leconte (1997) La famille et les langues, une étude sociolinguistique de la deuxième génération de $l^{\prime}$ immigration Africaine dans l' agglomération rouennaise. Paris: L'Harmattan.

Maalouf, A. (1998) Les identités meurtrières. Paris: Grasset.

Mackey, W.F. (1962) The description of bilingualism. Canadian Journal of Linguistics 7, 51-8.

Martin-Jones, M. and Jones (2000) (eds) Multilingual Literacies, Reading and Writing Different Worlds. Amsterdam/Philadelphia: John Benjamins Publishing Company.

Martin-Jones, M. and Romaine, S. (1986) Semilingualism: A half baked theory of communicative competence. Applied Linguistics 7 (1), 26-38.

Moore, D. (1996) Les langues dans l'école aujourd'hui: Pratique duelle ou duel de langues ou si 'europhonie' rimait avec 'heureuses phonies'. In Des utopies à construire, Hommages à Jacques André Tschoumy (pp. 69-73). Neuchâtel: IRDP-LEP.

Perregaux, C. (1998) Avec les approches d'éveil au langage, l'interculturel est au centre de l'apprentissage scolaire. Bulletin Suisse de Linguistique Appliquée 67, 101-110.

Nagy, C. (1996) L'éveil au langage: Contribution à l'étude de l'activité métalangagière de l'enfant à l'école élémentaire. PhD thesis, Université Stendhal, Grenoble.

Romaine, S. (1989) Bilingualism. Oxford: Basil Blackwell.

Saunders, G. (1988) Bilingual Children:From Birth to Teens. Clevedon: Multilingual Matters.

Sierra, J. and Olazigeri, I. (1991) E.I.F.E. 3: Influence on Factors on the Learning of Basque. Vitoria-Gasteiz: Central Publications of the Basque Government.

Toukomaa, P. and Skutnabb-Kangas, T. (1977) The Intensive Teaching of the Mother Tongue to Migrant Children at Pre-school Age. Research Report no. 26. Department of Sociology and Social Psychology, University of Tampere.

Van Overbecke, M. (1972) Introduction au bilinguisme. Bruxelles: Nathan.

Vermes, G. and Boutet, J. ( 1987) France, pays multilingue (Tomes 1 et 2). Paris: L'Harmattan.

Vygotsky, L.S. (1978) Mind in Society. Cambridge, MA: Harvard University Press. 